\title{
Konsep Diri Penderita TB Paru dengan Karies Gigi di Wilayah Kerja UPT Puskesmas Ambunten Kecamatan Ambunten Kabupaten Sumenep
}

(Self-Concept of Pulmonary TB Patients with Dental Caries in the Working Area of the UPT Puskesmas Ambunten, Sumenep)

Emdat Suprayitno,Mujib Hannan, Ummi Afifah

Fakultas IImu kesehatan Universitas Wiraraja

\begin{abstract}
Abstrak
TB paru masih menjadi masalah kesehtan global utama. Hal ini menyebabkan kesehatan yang buruk diantara jutaan orang tiap tahun dan peringkat kedua penyebab utama kamatian dari penyakit menular di seluruh dunia setelah Human Immunolodefisiensi Virus. Penyakit ini dapat diderita oleh setiap orang dan dapat menyebabkan perubahan fisik, mental, dan sosial. Keadaan ini dapat mempengaruhi konsep diri penderitanya. Tujuan penelitian ini untuk mengetahui seberapa besar penderita TB dengan karies gigi yang mengalami ganguan konsep diri. Desain Penelitian ini merupakan penelitian deskriptif kuantitatif dengan menggunakan design cross sectional non analitik. Populasi dalam penelitian ini adalah semua penderita TB paru dengan karies gigi sebanyak 64 orang, dengan menggunakan teknik total sampling. Variabel dalam penelitian ini adalah konsep diri penderita TB Paru dengan karies gigi. Hasil penelitian menunjukkan penderita TB paru di Wilayah Kerja Puskesmas Ambunten Kecamatan Ambunten Kabupaten Sumenep Tahun 2018, menunjukkan dari 64 respondent yang diteliti mengalami gangguan konsep diri dimana sebagian besar 36 orang (56\%) mengalami konsep diri ngatif dan 28 orang (43.8\%) dalam konsep diri yang positif. Kesimpulan penelitian konsep diri penderita TB paru yaitu, dimana orang yang menderita penyakit TB paru sebagain besar masih megalami gangguan konsep diri yang negatif.
\end{abstract}

Kata kunci : Konsep diri, Karies gigi, tuberkulosis paru

\section{Abstract}

Pulmonary TB is still a major global health problem. It causes ill-health among millions of people every year and ranks the second leading cause of death from infectious diseases worldwide after Human Immunodeficiency Virus. This disease can affect anyone and can cause physical, mental, and social changes. This situation can affect the sufferer's self-concept. The purpose of this study was to determine how many TB patients with dental caries experienced impaired self-concept. Design This research is a quantitative descriptive study using a cross-sectional non-analytic design. The population in this study were all 64 patients with pulmonary tuberculosis with dental caries, using a total sampling technique. The variable in this study was the self-concept of pulmonary tuberculosis patients with dental caries.The results showed that patients with pulmonary tuberculosis in the Work Area of the Ambunten Health Center, Ambunten District, Sumenep Regency in 2018, showed that of the 64 respondents studied had a selfconcept disorder where most 36 people (56\%) experienced negative self-concept and 28 people (43.8\%) had a conceptual disorder. positive self. The conclusion of the self-concept study of pulmonary tuberculosis patients is that most people who suffer from pulmonary TB disease still experience negative self-concept disorders.

Keywords: Dental caries, Pulmonary tuberculosis, Dental caries

Korespondensi (Corresondence) : Emdat Suprayitno. Fakultas IImu Kesehatan, Universitas Wiraraja. Jl. Raya Sumenep-Pamekasan km 05 Patean, Batuan, Kabupaten Sumenep, Jawa Timur 69451 E-mail: emdat@wiraraja.ac.id

TB paru merupakan penyakit infeksi menular yang disebabkan oleh kuman Mycobacterium tuberculosis. TB paru masih menjadi masalah kesehatan global utama. Hal ini menyebabkan kesehatan yang buruk diantara jutaan orang setiap tahun dan peringkat kedua penyebab utama kematian dari penyakit menular diseluruh dunia setelah Human Immunolodeficiency Virus.' Penyakit ini dapat di derita oleh setiap orang, tetapi paling sering ditemukan pada usia muda atau usia produktif yaitu 15-50 tahun, terutama mereka yang bertubuh lemah,kurang gizi, atau yang tinggal satu rumah dan berdesakdesakan bersama penderita TB paru. ${ }^{2}$

Lingkungan yang lembab, gelap dan tidak memiliki ventilasi memberikan andil besar bagi seseorang terjangkit penyakit TB paru. Penyakit TB paru sangat cepat menyebar dan menginfeksi manusia terutam bagi kelompok social ekonomi rendah dan kurang gizi. Kecepatan penyebaran dan infeksi penyakit TB paru sangat tnggi, maka tidak berlebihan jika penyakit TB paru merupakan penyakit yang mematikan. ${ }^{3}$

Berdasarkan global tuberculosis control tahun 2011 angka prevalensi semua tipe TB adalah sebesar 289 per 100.000 penduduk atau sekitar 690.000 kasus. Insedensi kasus baru TB paru dengan TBA poitif sebesar 189 per 100.000 penduduk atau sekitar 450.000 kasus. Kematian akibat TB di luar HIV sebesar 27 per 100.000 penduduk atau 182 orang per hari. Menurut laporan WHO tahun 2013 ,Indonesia menempati urutan ke tiga jumlah kasus TB paru setelah India dan Cina dengan jumlah sebesar 700 ribu kasus. Angka kematian masih sama dengan tahun 2011 sebesar 27 per 100.000 penduduk. ${ }^{4}$ Indonesia merupakan salah satu negara dengan jumlah kasus TB paru BTA positif mencapai 122.533 jiwa meliputi 86,9 \% laki-laki sejumlah 106.451 jiwa dan $13,1 \%$ perempuan sejumlah 16.076 jiwa. Berdasarkan prevelansi WHO tahun 2013 tingkat kejadian TB Paru di Indonesia masuk dalam kelompok urutan keempat setelah 
India, China, Afrika Selatan. Indonesia yang paling banyak dijumpai dengan diagnose TB paru yakni Provinsi Jawa Tengah sebesar $0,4 \% .{ }^{5}$ Berdasarkan hasil riset profil Dinkes Provinsi Jawa Tengah (2015), ditemukan jumlah kasus baru BTA+ sebanyak 672 kasus, naik bila dibandingkan kasus BTA + yang ditemukan tahun 2014 yang sebesar 435 kasus. 6

Pada tahun 2016 di kabupaten Sumenep jumlah kasus baru TB Paru dengan BTA positif sebesar 626 kasus. Untuk angka kesembuhan pada tahun 2016 sebesar 790 kasus dari 944 kasus yang di obati dengan angka keberhasilan 92,27\%. Berdasarkan data yang di dapat di Dinkes Kabupaten Sumenep tahun 2017 kecamatan Ambunten dalam peringkat kedua terbanyak setelah Batangbatang yang berjumlah 91 penderita dan berdasarkan data yang ada di wilayah kerja UPT Puskesmas Ambunten Kecamatan Ambunten jumlah penderita TB paru pada tahun 2017 sebanyak 64 penderita, dimana jumlah pada penderita TB paru laki-laki sebanyak 25 penderita dan pada perempuan sebanyak 39 pendrita, dari beberapa orang yang saya temui mengalami konsep diri yang berubah dimana pada penderita mengalami perubahan pada fisik, dan juga mengatakan malu berikteraksi pada masyarakat sekitar dikarnakan takut penyakitnya menular.?

Penderita TB Paru, biasanya mengalami perubahan bentuk fisik menjadi lebih kurus dan tampak pucat, sering batuk-batuk, badan lemah dan kemampuan fisikpun menurun. Pada usia dewasa pertengahan merupakan upaya untuk melaksanakan gaya hidup sehat karena banyak perubahanperubahan fisiologis yang terjadi, seperti menurunnya daya tahan tubuh sehingga rentan terhadap berbagai penyakit.8 Kondisi kesehatan fisik yang menurun akibat menderita suatu penyakit pada penderita penyakit TB paru juga dapat menimbulkan masalah lain terkait kondisi psikologis penderita. Sulistiyawati dan Kurniawati (2012) mengatakan bahwa TB Paru dapat mengganggu keadaan fisik dan psikososial penderita yang mempengaruhi harga diri penderita TB Paru. Penderita TB Paru dengan pengobatan lama akan mengalami tekanan psikologis dan merasa tidak berharga bagi keluarga dan masyarakat. Hal ini dapat mengalami gangguan konsep diri. ${ }^{9}$

Masalah konsep diri perlu mendapatkan penanganan yang tepat karena jika tidak hal ini dapat menyebabkan timbulnya masalah psikologis yang lebih serius. Selain dapat mengalami masalah psikososial berupa harga diri situasional akibat kondisi kesehatannya yang menurun juga dapat mengalami masalah kecemasan akibat merasakan ketidaknyamanan, kekhawatiran atau ketakutan terkait kondisi kesehatannya.10 Perlunya memberikan keperawatan terhadap masalah konsep diriyang situasional pada penderita TB paru akan sangat bermanfaat untuk mencegah terjadinya masalah psikologis yang lebih berat. Hal ini perlu dilakukan rencana dan tindakan yang bertujuan untuk meningkatkan kembali harga diri klien sehingga klien dapat mencapai tingkat aktualisasi diri yang maksimal dan menyadari potensi yang dimilikinya. ${ }^{11}$

\section{METODE PENELITIAN}

Penelitian ini merupakan deskriptif dengan design cross sectional. Teknik sampling dalam peneltian ini yaitu total sampling. Populasi dalam penelitian ini adalah seluruh penderita TB paru di Kecamatan Ambunten sebanyak 91 orang. kriteria inklusi: Penderita TB yang terdapat di wilayah kerja UPT puskesmas Ambunten Tahun 2018, penderita TB Paru yang bersedia menjadi responden dan penderita Tb paru yang mengalami karies gigi. Kriteria ekslusi yaitu penderita Tb Paru yang menalami komplikasi seperti sesak nafas, mengundurkan diri dan penderita Tb paru yang masih rawat inap. Jumlah sampel yaitu 64 orang penderita TB Paru dengan karies gigi. Penelitian ini dilakukan di wilayah kerja puskesmas Ambunten Kabupaten Sumenep pada tahun 2019. Instrument dalam penelitian ini yaitu kuesioner tentang konsep diri penderita TB Paru. Variabel penelitian ini adalah konsep diri TB paru dengan kategori positif dan negative. Dikatakan positif jika apabila nilai total skor $\geq$ Mean dan Negatif, apabila nilai total skor < Mean.

\section{HASIL PENELITIAN}

Tabel 1. Karakteristik umum responden

\begin{tabular}{lcc}
\hline $\begin{array}{l}\text { Karakteristik } \\
\text { Responden }\end{array}$ & Jumlah & $\%$ \\
\hline Usia & 10 & 15,6 \\
$22-26$ & 21 & 32,8 \\
$27-31$ & 15 & 23,5 \\
$32-36$ & 8 & 12,5 \\
$37-41$ & 10 & 15.6 \\
$42-46$ & & \\
\hline Pendidikan & 25 & 39,1 \\
SD & 21 & 32.8 \\
SMP & 10 & 15,6 \\
SMA & 8 & 12.5 \\
Tidak Sekolah & 8 & 12,1 \\
Perguruan tinggi & & \\
\hline Jenis kelamin & 25 & 35 \\
Perempuan & 39 & 65 \\
Laki-laki & & \\
\hline Pekerjaan & 27 & 42.2 \\
petani & 16 & 25.0 \\
Swasta & 13 & 20.3 \\
nelayan & 8 & 12.5 \\
tidak bekerja & 64 & 100 \\
\hline Total & & \\
\hline
\end{tabular}

Berdasarkan tabel 1 menunjukkan bahwa sebagian besar jenis kelamin responden adalah perempuan yaitu sebanyak 39 orang (65\%). Sebagian besar usia responden adalah 27-31 tahun yaitu 
sebanyak 21 orang (100\%). hampir setengah pendidikan responden adalah SMA yaitu sebanyak 25 orang (39.1\%). Sebagian besar pekerja responden adalah petani sabanyak 27 orang (42.2\%).

Tabel 2. Konsep diri penderita TB paru dengan karies gigi

\begin{tabular}{cccc}
\hline \multirow{2}{*}{ Konsep diri } & \multicolumn{2}{c}{ Penderita TB paru } & Jumlah \\
\cline { 2 - 3 } & $\mathbf{N}$ & $\mathbf{\%}$ & \\
\hline Negatif & 36 & 56,2 & 56,2 \\
\hline Positif & 28 & 43,8 & 43,8 \\
\hline Jumlah & 64 & 100 & 100 \\
\hline N, jumlah responden; \%, persentase &
\end{tabular}

Berdasarkan tabel 2 menunjukkan bahwa sebagian besar konsep diri penderita Tb Paru adalah Kurang Baik sebanyak 36 orang $(56,2 \%)$, dan sebagian lagi konsepdiri pada penderita TB paru yang Baik sebanyak 28 orang $(43,8 \%)$.

\section{PEMBAHASAN}

Menurut Crofton et al dalam Purnamasari (2010), angka kejadian TB pada pria selalu cukup tinggi pada semua usia tetapi pada wanita cenderung menurun tajam sesudah melampui usia subur. Wanita prevalensi TB mencapai maksimum pada usia 40-50 tahun dan kemudian berkurang, sedangkan pada pria prevalensi terus meningkat sampai sekurang-kurangnya mencapai usia 60 tahun.12 Menurut Dye dalam Zaman (2010) pria lebih sering terkena TB daripada wanita. Kasus TB di sebagian besar negara lebih tinggi pada pria daripada wanita. Rasio wanita terhadap kasus TB lakilaki dilaporkan secara global adalah 0,47 : 0,67 .

Penyebab perbedaan prevalensi TB berdasarkan jenis kelamin, belum dapat dipastikan. Perbedaan ini kemungkinan disebabkan oleh adanya perbedaan dalam faktor risiko infeksi, tingkat perkembangan dari infeksi menjadi penyakit, rendahnya pelaporan kasus TB pada wanita, atau perbedaan akses pelayanan. produktif yaitu usia 15-64 tahun. Berdasarkan penelitian Manalu (2010), penyakit TB paru paling sering ditemukan pada usia muda atau usia produktif 15-50 tahun. Hal serupa juga diungkapkan oleh Nurjana (2015) bahwa usia produktif merupakan usia dimana seseorang berada pada tahap untuk bekerja/menghasilkan sesuatu baik untuk diri sendiri maupun orang lain. $75 \%$ penderita TB paru ditemukan pada usia yang paling produktif secara ekonomi (15-49 tahun)..$^{13}$ Tingkat pendidikan seseorang akan mempengaruhi terhadap pengetahuan seseorang diantaranya mengenai rumah yang memenuhi syarat kesehatan dan pengetahuan penyakit TB paru, sehingga dengan pengetahuan yang cukup maka seseorang akan mencoba untuk mempunyai perilaku hisup bersih dan sehat. Selain itu tingkat pendidikan seseorang akan mempengaruhi jenis pekerjaannya. ${ }^{14}$ Kelompok masyarakat dengan tingkat pendidikan rendah umumnya adalah kelompok masyarakat dengan status ekonomi rendah. Kelompok msyarakat tersebut sulit untuk meyerap informasi mengenai kesehatan. Selain itu kelompok masyarakat dengan tingkat ekonomi dan pendidikan rendah juga tidak mampu mencukupi gizi dan pengadaan sarana sanitasi yang diperlukan..$^{15}$ Hasil penelitian menunjukkan sebagian besar konsep diri pada penderita TB paru di Puskesmas Ambunten Kecamatan Ambunten Kabupaten Sumenep Tahun 2018 adalah negatif yaitu sebanyak 36 orang $(56,2 \%)$. Sejalan dengan hasil penelitian suprayitno (2017) didapatkan data efikasi diri pada penderita PPOK memiliki efikasi diri tidak baik sebanyak $86,7 \% .^{4}$

Menurut Riyadi \& Purwanto (2009) Konsep diri yang negatif adalah timbul diri kurangnya kepercayaan kepada kemampuan sendiri. Orang yang tidak menyayangi dirinya merasa bahwa dirinya tidak akan mampu mengatasi persoalan. Orang yang percaya diri akan cenderung sedapat mungkin menghindari situasi kominikasi. la takut orang lain akan mengejeknya atau menyalahkannya. ${ }^{16}$ Orang yang takut dalam interaksi sosial, akan menarik diri dalam pergaulan, berusaha sekecil mungkin berkomunikasi, dan akan berbicara apabila erdesak saja. Tentu tidak semua ketakutan komunikasi di sebabkan kurangnya percaya diri, tetapi di antara bebagai faktor, percaya diri, seperti perubahan penampilan tubuh akibat penyakit yang di derita. ${ }^{17}$ Hasil penelitian ini juga di dukung oleh penelitian yang dilakukan oleh Imam Thohari, (2016) dengan judul " Konsep Diri Pada Pasien TB Paru" dengan hasil penelitian mengenai gambaran diri pada pasien TB paru, informen mengatakan badan kurus, berat badan turun, lemah, cepat capek, merasa minder, tidak percaya diri, seperti tidak berguna, malu mau ngumpul, mensykuri,tidak bisa kemana-mana, cuma dirumah saja, jaga jarak, menjauh, tida ikut kegiatan di masyarakat, seperti putus hubungan di masyarakat, seperti di asingkan. ${ }^{13}$ Menurut Yuliana dkk (2012) kosep diri yang negatif dapat dilihat dari hubungan individu dan sosial. Konsep diri terdiri atas gambaran diri, ideal, harga diri, peran diri, dan identitas diri. Harga diri adalah penilaian pribadi terhadap hasil yang di capai dengan menganalisa seberapa jauh prilaku memenuhi ideal diri. Gambaran diri adalah sikap individu terhadap dirinya baik disadari maupun tidak meliputi persepsi masalalu atau sekarang.

Ideal diri adalah persepsi individu tentang bagaimana yang seharusnya bertingkah laku berdasarkan standar pribadi. Identitas diri adalah kesadaran tentang diri sendiri yang dapat diperoleh individu dari observasi dan penilaian dirinya. ${ }^{18}$ Perubahan 
penampilan tubuh, seperti amputasi, cacat pada wajah, atau jaringan parut akibat luka bakar, merupakan tekanan yang sangat mempengaruhi citra tubuh. Mastektomi dan kolostomi merupakan prosedur bedah yang dapat mengubah penampilan dan fungsi tubuh, tapi Perubahan tersebut tidak terlihat oleh orang lain, Jika individu tersebut memakai pakaian. ${ }^{19}$ Meskipun tidak terlihat oleh orang lain, tetapi perubahan tubuh tersebut memiliki dampak yang signifikan bagi individu itu sendiri. Bahkan beberapa pilihan perubahan, seperti penambahan dan pengurangan payudara, dapat mempengaruhi citra tubuh. Penyakit kronis seperti penyakit jantung dan ginjal mempengaruhi citra tubuh karena tubuh tidak mampu berfungsi secara optimal lebih lama. Selain itu, efek kehamilan, penambahan atau penurunan berat badan yang signifikan, terapi farmakologis, atau terapi radiasi juga dapat mengubah citra tubuh. Citra tubuh yang negatif akan menyebabkan penambahan biaya kesehatan. ${ }^{20}$

Penelitian yang dilakukan Sulistiyawati dan Kurniawati (2012) "Hubungan Antara Harga Diri Dengan Prilaku Pada Pasien TB Paru" mengatakan bahwa TB Paru dapat mengganggu keadaan fisik dan psikososial penderita yang mempengaruhi harga diri penderita TB Paru. Penderita TB Paru dengan pengobatan lama akan mengalami tekanan psikologis dan merasa tidak berharga bagi keluarga dan masyarakat. ${ }^{17}$ Hal ini dapat mengalami gangguan konsep diri. Stuart dan Sundeen (1991, dalam Riyadi \& Purwanto, 2009) mengatakan bahwa konsep diri adalah semua ide, pikiran, kepercayaan dan pendirian yang diketahui individu tentang dirinya dan mempengaruhi individu dalam berhubungan dengan orang lain. Konsep diri negative dapat dilihat dari hubungan individu dan social yang maladaptive. Konsep diri terdiri dari komponen-komponen yaitu citra tubuh, ideal diri, harga diri, peran diri dan identitas diri.21

Konsep diri yang negatif timbul dari kurangnya kepercayaan kepada kempuan sendiri. Orang yang tidak menyayangi dirinya merasa bahwa dirinya tidak akan mampu mengatasi persoalan. Orang yang percaya diri akan cenderung sedapat mungkin menghindari situasi kominikasi. la takut orang lain akan mengejeknya atau menylahkannya. Orang yang takut dalam interaksi sosial, akan menarik diri dalam pergaulan, berusaha sekecil mungkin berkomunikasi, dan akan berbicara apabila erdesak saja. Tentu tidak semua ketakutan komunikasi di sebabkan kurangnya percaya diri. ${ }^{20}$

Penelitian yang dilakukan Indah Ayu Novitasari,(2014) dengan judul "Hubungan Dukungan Keluarga Terhadap Konsep Diri Pada penderita TB Paru" Respondent yang mempunyai konsep diri kurang (negatif) di sebabkan oleh sebagian besar respondent yang mengalami batuk terus menerus mendarikan respondent sukit bergaul di lingkungan masyarakat, merasa minder dengan penyakit tuberculosis serta menimbulkan rasa tidak yakin bisa sembuh dalam menjalani pengobatan. Dimana penderita TB paru mengalami perubahan bentuk fiksik menjadi lebih kurus dan sering batuk-batuk, ragu-ragu untuk menunjukkan pendapat, bersikap pasif, merasa rendah diri dan menarik diri orang lain karna khawatir penyakit yang dideritanya menular kepada orang lain ini menunjukkan bahwa penayakit tuberculosis mempengaruhi konsep diri penderita. ${ }^{22}$ Keluarga berperan dalam menciptakan dan memelihara konsep diri setiap anggotanya. Seseorang juga membangun norma-norma yang diperbolehkan untuk berpikir, merasakan, dan berperilaku dari anggota keluarga. Terkadang keluarga yang baik akan menanamkan konsep diri negatif pada anak.13

Saat ini jumlah penderita TB paru di wilayah UPT Puskesmas Ambunten Kecamatan Ambunten Kabupaten sumenep meningkat sehingga perlunya penyuluhan cara mengantisipasi penyakit TB paru dengan menjaga ventilasi dan pencahayaan rumah, juga perlunya dukungan keluarga dan lingkungan sekitar agar konsep diri yang negatif pada penderita TB paru dapat dihindari dan teratasi.

Berdasarkan hasil penelitian, dapat disimpulkan bahwa sebagian besar Konsep Diri pada penderita TB paru Di wilayah Puskesmas Ambunten Kecamatan Ambunten adalah negatif. Disarankan agar penderita TB Paru agar konsep dirinya menjadi positif dengan meningkatkan mekanisme koping yang baik.

\section{DAFTAR PUSTAKA}

1. Andayani S \& Astuti Y. Prediksi Kejadian Penyakit Tuberkulosis Paru Berdasarkan Usia Di Kabupaten Ponorogo Tahun 2016-2020. Indonesian Journal for Health Sciences, 2017; 1 (2), 29-33.

2. Harding, E. (2020). WHO global progress report on tuberculosis elimination. The Lancet Respiratory Medicine, 2020; 8(1), 19.

3. Hairuddin MC., \& Mariana D. Faktor risiko kejadian tuberkulosis paru di wilayah kerja Puskesmas Binanga Kabupaten Mamuju. Jurnal Penelitian Kesehatan" SUARA FORIKES"(Journal of Health Research" Forikes Voice"), 2017; $8(3), 140-5$.

4. Suprayitno E. Pengaruh Pursed Lips Breathing terhadap Peak Expiratory Flow Rate Penderita Penyakit Paru Obstruksi Kronis. Wiraraja Medika. 2018.

5. Ernawati K. Hubungan Merokok Dengan Kejadian Tuberkulosis Paru Di Provinsi Sulawesi Utara Berdasarkan Data 
Riskesdas Tahun 2010. Jurnal Kedokteran Yarsi, 2017; 25(1), 33-40.

6. Widiyanto A. Hubungan Kepatuhan Minum Obat dengan Kesembuhan Pasien Tuberkulosis Paru BTA Positif di Puskesmas Delanggu Kabupaten Klaten. Interest: Jurnal IImu Kesehatan, 2017; 6(1), 7-12.

7. Tamamengka D., Kepel B., \& Rompas $S$. Fungsi Afektif dan Perawatan Keluarga dengan Kepatuhan Pengobatan TB Paru. Jurnal Keperawatan, 2019; 7(2).

8. Kristinawati, B., Muryadewi, A., \& Irianti, A. D. The Role of Family as A Caregiver in Caring for Family Members that are Suffering from Pulmonary Tuberculosis. Jurnal Ners, 2019; 14(3), 362-6.

9. Sari NPWP., \& Sari AKE. Comparison of stress level and coping strategy between therapeutic phases in newly diagnosed tuberculosis. International Journal of Public Health, 2020; 9(2), 14552.

10. Permatasari D., \& Suprayitno E. Implementasi Kegiatan Pendidik Sebaya dan Konselor Sebaya dalam Upaya Pencegahan Triad KRR di Pusat Informasi dan Konseling Remaja. Jurnal Ners Dan Kebidanan (Journal of Ners and Midwifery), 2020; 7(1), 143-150.

11. Suprayitno E., Purnomo JDT., Sutikno S., \& Indriyani R. Health education in principle of community affected teenagaer's smooking attitude and habitual in the coastal area of madura island indonesia. International Journal of Psychosocial Rehabilitation, 2020; 24(10), 1492-502.

12. Murtono D. Gambaran Kejadian Tuberkulosis Di Kabupaten Pati. Jurnal Litbang: Media Informasi Penelitian, Pengembangan Dan IPTEK, 2017; 13(2), 115-26.

13. Siregar S., \& Tampubolon VS. Gambaran Status Gizi terhadap Kejadian Tb Paru di Rumah Sakit Imelda Medan Tahun 2018. Jurnal IImiah
Keperawatan Imelda, 2018; 4(2), 295308.

14. Muhammad EY. Hubungan Tingkat Pendidikan Terhadap Kejadian Tuberkulosis Paru. Jurnal IImiah Kesehatan Sandi Husada, 2019; 10(2), 288-91.

15. Suprayitno E., \& Huzaimah N. Pendampingan lansia dalam pencegahan komplikasi hipertensi. 2020; 4: 518-21.

16. Suprayitno E., \& Damayanti CN. Self Care Management of Hypertensive Patients in Pangarangan Village Sumenep City District, Sumenep Regency. Proceedings of International Interdisciplinary Conference on Sustainable Development Goals (IICSDGs), 2020; 3(1): 23-7.

17. Zenner D., Kruijshaar ME., Andrews N., \& Abubakar I. Risk of Tuberculosis in Pregnancy A National, Primary Care based Cohort and Self-controlled Case Series Study. 2018;14

18. Suprayitno, E., \& Damayanti, C. N. (n.d.). Intervensi Supportive Educative Berbasis Caring Meningkatkan Self Care Management Penderita Hipertensi. Dunia Keperawatan: Jurnal Keperawatan Dan Kesehatan, 2020; $8(3) ; 460-7$.

19. Suprayitno E., Pratiwi IGD., \& Yasin Z. Gambaran Penyebab Terjadinya Pembengkakan Payudara Pada Ibu Menyusui Di Polindes Desa Meddelen Kecamatan Lenteng. WIRARAJA MEDIKA, 2018; 8(1), 13-18.

20. Potter P. Nursing, Fundamental of. EGC. 2016

21. Desri Suryani D. Analisis Pola Makan dan Anemia Gizi Besi Pada Remaja Putri kota Bengkulu. 2015; 11-18.

22. Suryani U., \& Efendi Z. Dukungan Keluarga Berhubungan dengan Harga Diri pada Penderita Tuberkulosis Paru. Jurnal IImu Keperawatan Jiwa, 2020; 3(1): 53-8 